\title{
Nitrogén, réz és molibdén kölcsönhatások lucerna kultúrában (Medicago sativa L.)
}

\author{
KÁDÁr Imre \\ MTA ATK Talajtani és Agrokémiai Intézet, Budapest

\section{Bevezetés és irodalmi áttekintés}

A rezet régóta széleskörüen hasznosítjuk, ezért szóródása és akkumulációja nyomon követhető a környezeti elemekben. Komló és szőlő kultúrákban a talajok Cu-készlete a feltalajban akár nagyságrenddel megnőhet a Cu-tartalmú növényvédőszerek tartós használata miatt. Elöször Franciaországban 1882-ben kezdték a $\mathrm{CuSO}_{4}$ 5\%-os oldatát alkalmazni gyomirtószerként Bordeaux város közelében, ezért vált „,bordói” léként ismertté. Később 0,1-0,2\%-os oldata is elterjedt mint gombaölő szer. A Cu-toxikózis mérsékelhető szervestrágyázással, meszezéssel, illetve az antagonista P, Fe, Mo elemek bevitelével. A Cu-többletre különösen érzékenyek lehetnek a lucerna, a herefélék és a mák (BOWEN 1979).

A $\mathrm{Cu}$ túlsúlya természetszerủen kiugró lehet rézbányák közelében, meddőhányókon. Újkori Cu-terhelést jelenthet a sertéstrágya. A sertések takarmányát rézsókkal egészítik ki a jobb takarmányhasznosulás céljából. A takarmány Cu-tartalma elérheti akár a $250 \mathrm{mg}^{\circ} \mathrm{kg}^{-1}$ értéket. A sertéstrágya $\mathrm{Cu}$ készlete ebből adódóan nagyságrendekkel nőhet, mely a talaj nemkívánatos $\mathrm{Cu}$ terhelését eredményezheti. Saját elemzéseink szerint egy vizsgált sertéshizlalda trágyájában $(\mathrm{n}=8) \quad 380-530 \mathrm{mg} \mathrm{kg}^{-1} \mathrm{Cu}$-tartalmat mértünk a szárazanyagban (KÁDÁr 2011).

A $\mathrm{Cu}$ hiánya is gyakori. A gabonafélék tőzeges talajon gyakran nem fejlesztenek kalászt. Felléphet másodlagos vagy indukált $\mathrm{Cu}$-hiány rétláp talajokon a Mo-felesleg miatt. TÖLGYESI (1965) vizsgálatai rámutattak arra is, hogy pl. a keszthelyi lápon termett növényekben egyidejüleg fennállhat a $\mathrm{Cu}$ hiánya és a Mo többlete. A szervesanyagban gazdag talajok ugyanis Mo-ban is gazdagok, míg a rezet megkötik. Az élettanilag kívánatos 5-10 körüli Cu:Mo arány a takarmányban akár 0,1-0,2 értékre szükülhet Mo-toxikózist okozva. A legeltetett juh és marha anémiás lépbetegségét a Cu-hiányra, illetve a Mo-bőségre vezetik vissza (BERGMANN 1992).

A hazai talajok összes Cu-tartalma $10-110 \mathrm{kgha}^{-1}$ mennyiségre tehető a szántott rétegben GYÖRI (1984) adatai alapján, aki 3-38 $\mathrm{mg} \mathrm{kg}^{-1}$ összes Cu-készletet talált eltérő talajokban. Egy nemzetközi FAO felmérésben a hazai talajok $(\mathrm{n}=250)$ NH4-acetát+EDTA oldható Cu-tartalma 1-15 $\mathrm{mgkg}^{-1}$ tartományban ingadozott. Hazánk az 5,4 mg kg-1 átlagos értékkel a nemzetközi rangsor „középmezőnyében” foglalt helyet. A vizsgált talajokon termett bokrosodáskori búza $(\mathrm{n}=144) 8,5$ mg $\mathrm{kg}^{-1}$, míg a 4-6 leveles korú kukorica hajtása $(\mathrm{n}=106) 15,0 \mathrm{mg} \mathrm{kg}^{-1}$ átlagos $\mathrm{Cu}$ Postai cím: KÁDÁR IMRE, MTA ATK TAKI, 1022 Budapest, Herman Ottó út 15. E-mail: kadar.imre@agrar.mta.hu 
koncentrációt mutatott illeszkedve a nemzetközi középértékhez (SILLANPäÄ 1982, KÁDÁR 1995). Megemlíthető, hogy lápi termőhelyek nem voltak képviselve a magyar FAO mintákban.

Mezőföldi mészlepedékes csernozjom vályogtalajon beállított mütrágyázási tartamkísérletünkben a pillangósnélküli gyepszéna Cu-tartalma $2,1 \mathrm{mg} \mathrm{kg}^{-1}$ értékröl $4,7 \mathrm{mg} \mathrm{kg}^{-1}$ értékre nőtt igazolhatóan a N-trágyázással. A PK ellátottsági szintek érdemi hatással nem voltak a Cu-tartalomra. A Mo koncentrációja ugyanakkor a kontrollon mért $0,44 \mathrm{mg} \mathrm{kg}^{-1}$-ról $0,05 \mathrm{mg} \mathrm{kg}^{-1}$-ra csökkent az együttes, bőséges NPK-kínálat nyomán. A széna eredeti 5 körüli Cu:Mo aránya így 94 körülire tágult. Tehát a széna relatíve Mo-hiányossá vált az NPK mütrágyázással. Valójában a talaj Mo-készlete nem módosult, csupán a növényi Mo-felvételt gátolta. A jelenség tehát talajvizsgálatokkal nem ismerhető meg, csak a növényelemzés tárhatja fel a mechanizmust (KÁDÁR 2013, KÁDÁR és CSATHÓ 2017).

A $\mathrm{N} \times \mathrm{Cu}$ elemek közötti kölcsönhatásokat tenyészedény kísérletekben is vizsgáltuk meszes homok és vályog talajokkal, árpa és köles jelzőnövénnyel. A $\mathrm{CuSO}_{4}$ formában adott $\mathrm{Cu}$-terhelést a $\mathrm{KCl}+\mathrm{EDTA}$ oldható $\mathrm{Cu}$-tartalom jól tükrözte mindkét talajban. A növényi hozamokat a Cu-trágyázás nem befolyásolta. A mintegy $10 \mathrm{mg} \mathrm{kg}^{-1} \mathrm{Cu}$-adaggal a tavaszi árpa gyökereinek Cu-tartalma vályogtalajon $10-15 \mathrm{mg} \mathrm{kg}^{-1}$, homoktalajon $30-40 \mathrm{mg} \mathrm{kg}^{-1}$ értékkel nőtt meg. A földfeletti hajtás $\mathrm{Cu}$-koncentrációja ugyanakkor nem módosult érdemben, a $\mathrm{Cu}$ növényen belüli transzportja gátolt volt. A N-bőség bizonyos határig igazolhatóan növelte a Cu beépülését a gyökerekbe (KÁDÁR ÉS SHALABY 1985).

Bizonyos talajokon a bőséges P-trágyázás szintén növelheti a Mo növényi felvételét, míg a Cu-felvételt gátolja, hiányt indukálva. $\mathrm{A} \mathrm{Cu}$ beépülését az állati szervezetbe a kénbőség szintén akadályozhatja, amennyiben a bendőben felvehetetlen CuS keletkezhet. Az elöregedö füvek Cu-tartalma is gyakran csökken, mely a jelenséget erősítheti. A mütrágyázás drasztikus beavatkozást jelenthet a talajba és a rajta termő gyepre. A szakszerütlen és ellenőrizhetetlen mütrágyahasználat katasztrofális következményeire már közel fél évszázaddal ezelőtt rámutatott VoISIN (1965) Franciaországban. A szerző szerint a talaj-növényállat-ember sorsa összefügg. A humán civilizációs betegségek sem függetlenek végső soron a mütrágyázás gyakorlatától, nem beszélve a legelő állatnál megfigyelt anyagcsere és hiánybetegségekröl.

A Mo bár esszenciális elem, hiányát ritkán sikerül kimutatni növényben, állatban, emberben, mert az élővilág rendkívül kis mennyiségben igényli. A túlsúlya azonban problémát jelenthet. A talajban nem kötödik meg, így száraz vidékeken a $\mathrm{Na}, \mathrm{B}$, Se és egyéb mobilis elemekkel együtt a feltalajban dúsul. A talaj/növény rendszerben a szürő nem müködik, a növény hiperakkumulátorként halmozza fel a tömegárammal bejutó Mo-t. A Mo túlsúlya a takarmányban, legelőfüben mérgezést, molibdenózist, a legelőhasmenés tünetegyüttesét okozza. A vizet áteresztő kilúgzásos talajokon nem lép fel Mo toxicitás.

A szokásos Mo-tartalom a növényekben 0,1-2 $\mathrm{mgkg}^{-1}$ közötti. Az egészségügyi maximum a takarmányban $10-20 \mathrm{mg} \mathrm{kg}^{-1}$ CHANEY (1982), KLOKE et al. (1988), SAUERBECK (1985) szerint. Humántoxikológiai szempontból viszonylag 
„békés” elemnek tekintik a Mo-t. Ivóvizekre nincs is határkoncentráció megadva. $\mathrm{Az}$ 50/2001. (IV.3.) Korm. rendelet szerint a szennyvizekben 0,02 $\mathrm{mg}^{-1}$, szennyvíziszapokban $20 \mathrm{mg} \mathrm{kg}^{-1}$ a megengedett mezőgazdasági felhasználás esetén. A talaj ilyen módon $0,2 \mathrm{~kg} \mathrm{ha}^{-1} \mathrm{é}^{-1}$ Mo mennyiséggel terhelhető maximum $7 \mathrm{mg}$. $\mathrm{kg}^{-1}$ összes Mo-tartalom eléréséig a szántott rétegben. A kísérlet főbb eredményeit önálló kiadványban is összefoglaltuk (KÁDÁR és CsATHÓ 2017)

\section{Anyag és módszer}

A N x Cu kölcsönhatásokat vizsgáló kéttényezős kísérletet 1988 tavaszán állítottuk be az MTA ATK TAKI nagyhörcsöki kísérleti telepén. A kísérlet talaja löszön képződött meszes csernozjom mely a kísérlet beállítása elött 1988. március elején végzett talajvizsgálataink szerint mintegy $5 \% \mathrm{CaCO}_{3}$-ot és $3 \%$ humuszt tartalmazott a szántott rétegben. A pH(KCl) = 7,3; az AL- $\mathrm{P}_{2} \mathrm{O}_{5} 128 \mathrm{mg} \cdot \mathrm{kg}^{-1}$, AL$\mathrm{K}_{2} \mathrm{O} 243 \mathrm{mg} \cdot \mathrm{kg}^{-1}$, KCl-Mg 150-180 mg $\mathrm{kg}^{-1}$, az EDTA-Mn $127 \mathrm{mg} \cdot \mathrm{kg}^{-1}$, az EDTA$\mathrm{Cu} 2-3 \mathrm{mg} \cdot \mathrm{kg}^{-1}$, EDTA-Zn 1-2 $\mathrm{mg} \cdot \mathrm{kg}^{-1}$ értékekkel jellemezhetők. A KCl-oldható $\mathrm{NH}_{4}-\mathrm{N} 9, \mathrm{NO}_{3}-\mathrm{N} 12 \mathrm{mg} \cdot \mathrm{kg}^{-1}$ a feltalajban. A BUZÁs et al. (1979) által elfogadott módszerek és határértékek alapján ezek az adatok a talaj jó $\mathrm{Ca}, \mathrm{Mg}, \mathrm{K}, \mathrm{Mn}$; kielégítő $\mathrm{Cu}$, valamint gyenge $\mathrm{P}$ és $\mathrm{Zn}$ ellátottságáról tanúskodnak. A talajvíz szintje 13-15 m mélyen helyezkedik el, a terület aszályérzékeny. Éghajlata az Alföldéhez hasonlóan szárazságra hajló, átlagos középhőmérséklete $11^{\circ} \mathrm{C}$, éves átlagos csapadékösszege $576 \mathrm{~mm}$.

A kísérlet osztott parcellás (split-plot) elrendezésủ $4 \mathrm{Nx} 3 \mathrm{Cu}=12$ kezeléssel és 3 ismétléssel, összesen 36 parcellával. A parcellák mérete 4,9 x $15=73,5 \mathrm{~m}^{2}$ volt. Az alaptrágyázás évente $100 \mathrm{~kg} \cdot \mathrm{ha}^{-1} \mathrm{P}_{2} \mathrm{O}_{5}$ és $100 \mathrm{~kg} \cdot \mathrm{ha}^{-1} \mathrm{~K}_{2} \mathrm{O}$ adagot jelentett szuperfoszfát és kálisó formájában. A $\mathrm{N}-\mathrm{t} 25 \%$-os pétisó $\left(\mathrm{Ca}-\mathrm{NH}_{4} \mathrm{NO}_{3}\right), a \mathrm{Cu}$ trágyát 25,5\%-os $\mathrm{CuSO}_{4} \times 5 \mathrm{H}_{2} \mathrm{O}$ formában alkalmaztuk. A PK mütrágyákat és a $\mathrm{N}$ felét az elővetemény lucerna törésére szórtuk ki 1987 őszén és leszántottuk, míg a $\mathrm{N}$ másik felét és a $\mathrm{CuSO}_{4}$ trágyát 1988 tavaszán kevertük a talajba vetés előtt. Az 5. évben 1992 tavaszán a 15 m hosszú parcellákat megfeleztük és egy $1 \mathrm{~m}$-es úttal elválasztottuk. Az osztott parcellás (split-plot) elrendezésủ kísérletünk háromtényezőssé vált $4 \mathrm{~N} \times 3 \mathrm{Cu} \times 2 \mathrm{Mo}=24$ kezeléssel $\times 3$ ismétléssel $=72$ parcellával. A felezett parcellákra $48 \mathrm{~kg} \cdot \mathrm{ha}^{-1}$ Mo-t szórtunk ki N-fejtrágyával egyidőben. A Mo trágyát $\left(\mathrm{NH}_{4}\right)_{6} \mathrm{Mo}_{7} \mathrm{O}_{24} \cdot 4 \mathrm{H}_{2} \mathrm{O}$ formában adagoltuk. A $\mathrm{N}$ és a Mo sókat a következő napok csapadéka a talajba mosta. Tehát a Cu-trágyázás 1988-ban, Mo-trágyázás 1992-ben történt egyszeri alkalommal. A N, P és K mütrágyákat évente adtuk.

Vizsgált tényezők az alábbiak:

\begin{tabular}{|c|c|c|}
\hline 1. tényezö (föparcellák): & 2. tényezö (alparcellák): & 3. tényezö (al-alparcellák) \\
\hline $\mathrm{N}_{0}=$ kontroll & $\mathrm{Cu}_{0}=$ kontroll & Mo $=$ kontroll \\
\hline $\mathrm{N}_{1}=100 \mathrm{~kg} \cdot \mathrm{ha}^{-1} \cdot$ év $^{-1} \mathrm{~N}$ & $\mathrm{Cu}_{1}=50 \mathrm{~kg} \cdot \mathrm{ha}^{-1} \mathrm{Cu}$ 1988-ban & $\mathrm{Mo}=48 \mathrm{~kg} \cdot \mathrm{ha}^{-1} 1992$-ben \\
\hline $\begin{array}{l}\mathrm{N}_{2}=200 \mathrm{~kg} \cdot \mathrm{ha}^{-1} \cdot \mathrm{év}^{-1} \mathrm{~N} \\
\mathrm{~N}_{3}=300 \mathrm{~kg} \cdot \mathrm{ha}^{-1} \cdot \mathrm{e}^{-1} \mathrm{~N}\end{array}$ & $\mathrm{Cu}_{2}=100 \mathrm{~kg} \cdot \mathrm{ha}^{-1} \mathrm{Cu}$ 1988-ban & \\
\hline
\end{tabular}


A kísérlet 1. évében 1988-ban tavaszi árpa, 1989-ben öszi búza, 1990-ben öszi árpa, 1991-ben kukorica, 1992-ben tritikále, 1993-ban burgonya, 1994-ben zab, 1995-ben rozs volt a termesztett növény. A kísérlet 15 éven át folyt, a növényi sorrendet 1988-2002 között az 1. táblázat ismerteti.

\section{1. táblázat}

A N x Cu tartamkísérlet növényi sorrendje 1988-2003 között (Mészlepedékes csernozjom vályogtalaj, Nagyhörcsök, Mezőföld)

\begin{tabular}{|c|l|c|c|c|c|}
\hline Kísérlet & \multicolumn{1}{|c|}{ Növényfaj } & Fajta & Kísérlet & Növényfaj & Fajta \\
\hline $\begin{array}{c}\text { éve (1) } \\
1988\end{array}$ & $\begin{array}{c}\text { (forgó) (2) } \\
\text { tavaszi árpa }\end{array}$ & $\begin{array}{c}\text { (hibrid) (3) } \\
\text { Opal }\end{array}$ & $\begin{array}{c}\text { éve (1) } \\
1996\end{array}$ & $\begin{array}{c}\text { (forgó) (2) } \\
\text { lucerna(12) }\end{array}$ & $\begin{array}{c}\text { (hibrid) (3) } \\
\text { Szarvasi-1 }\end{array}$ \\
& (4) & & & & \\
1989 & öszi búza (5) & MV-15 & 1997 & lucerna(12) & Szarvasi-1 \\
1990 & öszi árpa (6) & MV-35 & 1998 & lucerna(12) & Szarvasi-1 \\
1991 & kukorica (7) & Pi 3732 & 1999 & lucerna(12) & Szarvasi-1 \\
& & & & & \\
1992 & triticale (8) & Presto & 2000 & repce (13) & Wester \\
1993 & burgonya (9) & Desirée & 2001 & mák (14) & Kék Duna \\
1994 & zab(10) & Leanda & 2002 & napraforgó (15) & IHNK hibrid \\
1995 & rozs(11) & Kisvárdai-1 & 2003 & tavaszi árpa (4) & Orbit \\
& & & & & \\
\hline
\end{tabular}

Laboratóriumi vizsgálatok az MTA ATK Talajtani és Agrokémiai Intézetben történtek az alább ismertetett módszerekkel:

Növényelemzés: A bemért $0,5 \mathrm{~g}$ légszáraz anyaghoz $5 \mathrm{~cm}^{3} \mathrm{cc} \cdot \mathrm{HNO}_{3}+1 \mathrm{~cm}^{3}$ cc. $\mathrm{H}_{2} \mathrm{O}_{2}$ adagolása, majd 15 perces roncsolás a mikrohullámú berendezésben. $\mathrm{Az}$ ásványi elemek mérése ICP-AES készüléken. A $\mathrm{N}$ meghatározása: $0,5 \mathrm{~g}$ légszáraz anyaghoz $10 \mathrm{~cm}^{3}$ cc. $\mathrm{H}_{2} \mathrm{SO}_{4}+\mathrm{cc} \cdot \mathrm{H}_{2} \mathrm{O}_{2}$ szükség szerint adagolva az ISO 11261 (1995), illetve a módosított KJELDAHL (1891) eljárással.

Talajelemzés: A $\mathrm{KCl}+$ EDTA oldható Cu-tartalmat, az AL-oldható PKtartalmat EGNÉR et al. (1960), valamint az $1 \mathrm{~mol}^{-1} \mathrm{KCl}$-kicserélhető $\mathrm{NH}_{4}-\mathrm{N}$ és $\mathrm{NO}_{3}-\mathrm{N}$ tartalmakat a MÉM NAK (1978), illetve BARANYAI et al. (1987) által ismertetett eljárásokkal vizsgáltuk. $\mathrm{Az} \mathrm{NH}_{4}$-acetát+EDTA oldható ásványi elemeket LAKANEN ÉS ERVIÖ(1971), a humuszt TYURIN (1937), az összes N-t az ISO 11261 (1995), illetve módosított KJELDAHL (1891) által ismertetettek alapján határoztuk meg.

Csapadékellátottság. A rozs elővetemény aratása 1995. július 20-án történt. Az év végéig még 201 mm eső esett. Az 1995-1999 közötti évek havi csapadékadatait és az éves csapadékösszegeket a 2. táblázat tekinti át. 


\section{2. táblázat}

A havi csapadékadatok és évi csapadékösszegek 1995-1999 között, mm (Mészlepedékes csernozjom vályogtalaj, Nagyhörcsök, Mezőföld)

\begin{tabular}{|c|c|c|c|c|c|c|}
\hline \multirow{2}{*}{ Hónapok (1) } & \multicolumn{5}{|c|}{ Évek (2) } & \multirow{2}{*}{$\begin{array}{c}50 \text { éves } \\
\text { átlag (3) }\end{array}$} \\
\hline & 1995 & 1996 & 1997 & 1998 & 1999 & \\
\hline Január & 12 & 4 & 0 & 54 & 15 & 29 \\
\hline Február & 53 & 15 & 8 & 0 & 44 & 29 \\
\hline Március & 33 & 3 & 13 & 28 & 17 & 31 \\
\hline Április & 38 & 11 & 8 & 104 & 87 & 42 \\
\hline Május & 37 & 63 & 53 & 79 & 77 & 47 \\
\hline Június & 89 & 41 & 60 & 37 & 192 & 71 \\
\hline Július & 30 & 15 & 50 & 63 & 129 & 54 \\
\hline Augusztus & 7 & 25 & 8 & 61 & 60 & 60 \\
\hline Szeptember & 87 & 160 & 4 & 114 & 19 & 47 \\
\hline Október & 7 & 0 & 37 & 73 & 53 & 40 \\
\hline November & 22 & 28 & 28 & 48 & 96 & 52 \\
\hline December & 68 & 42 & 50 & 22 & 42 & 40 \\
\hline $\begin{array}{l}\text { Éves összes } \\
\text { (4) }\end{array}$ & 483 & 407 & 319 & 682 & 830 & 536 \\
\hline
\end{tabular}

Látható, hogy a lucerna vetéséig 1996. április közepéig 1996-ban szárazság uralkodott, az év egészében $407 \mathrm{~mm}$ eső hullott. Az éves csapadékhozamokat tekintve legszegényebb év az 1997 volt, míg csapadékban bővelkedett az 1999. Megemlíthető, hogy a vizsgált vályogtalaj $1 \mathrm{~m}$ rétegének szabadföldi vízkapacitása (VKsz) $300 \mathrm{~mm}$ körüli. A holtvíztartalom (HV) $140 \mathrm{~mm}$, a hasznosítható vagy diszponibilis vízkészlet (DV) pedig $160 \mathrm{~mm}$ mennyiségre tehető. Ez az induló vízkészlet részben rendelkezésére állhatott a lucernának, amennyiben az elövetemény betakarítása és a lucerna vetése között eltelt közel 9 hónap alatt lehullott $234 \mathrm{~mm}$ csapadék döntően a fedetlen talajba szivárgott és a párolgástól is eltekintünk.

A vetés 1996. április 17-én történt Szarvasi 1 fajtával 1-2 cm mélyen gabona sortávra, $1200 \mathrm{db} \mathrm{m}^{-2}$ csíraszámmal és $24 \mathrm{~kg} \cdot \mathrm{ha}^{-1}$ vetőmagnormával. Az állomány bonitálásokat és a kaszálásokat zöldbimbós állapotban végeztük. Kaszálásonként és parcellánként 15-20 helyről gyüjtött növényi átlagminta anyaga szolgált analitikai célokra. Az értékelt nettó parcella méret 7 x $1,5=10,5 \mathrm{~m}^{2}$ volt a gépi kaszálásnak megfelelően. A kísérletben alkalmazott agrotechnikai müveletekről és módszertani beavatkozásokról, illetve megfigyelésekröl a 3. táblázat tájékoztat. 


\section{3. táblázat}

Agrotechnikai műveletek és megfigyelések a N x Cu lucerna tartamkísérletben 1996-1999 között (Mészlepedékes csernozjom vályogtalaj, Nagyhörcsök, Mezöföld)

\begin{tabular}{|c|c|c|}
\hline Müveletek megnevezése (1) & Időpont (2) & Egyéb megjegyzés (3) \\
\hline 1.Öszi mütrágyázás (NPK) & 1995.10.20. & Parcellánként kézzel \\
\hline 2.Egyirányú szántás & 1995.11.14. & MTZ-80+Lajta eke \\
\hline 3.Tavaszi N-műtrágyázás & 1996.04.10. & Parcellánként kézzel \\
\hline 4.Vetőágykészítés & 1996.04.11. & MTZ-80+kombinátor \\
\hline 5.Vetés (Szarvasi 1) & 1996.04.17. & MTZ-80+Lajta vetőgép \\
\hline 6.Magtakarás & 1996.04.17. & T4K-14+sima henger \\
\hline 7.Állomány sorol vontatottan & 1996.05.06. & Egész kísérletben egységesen \\
\hline 8.Gazoló kaszálás & 1996.07.31. & T4K+fükasza \\
\hline 9.Bonitálás zöldbimbós korban & 1996.09.30. & Parcellánként 1-5 skálán \\
\hline 10.Kaszálás (T4K+fükasza) & 1996.09.30. & Parcellánként 7 x 1,5 = 10,5 m² \\
\hline 1.Mütrágyázás (NPK) & 1997.04.02. & Parcellánként kézzel \\
\hline 2.Bonitálás zöldbimbós korban & 1997.05.20. & Parcellánként 1-5 skálán \\
\hline 3.Kaszálás (T4K+fükasza) & 1997.05.20. & Parcellánként 7 x 1,5 = 10,5 m² \\
\hline 4. Kaszálás (T4K+fükasza) & 1997.06.30. & Parcellánként 7 x 1,5 = 10,5 m² \\
\hline 5. Kaszálás (T4K+fükasza) & 1997.08.05. & Parcellánként 7 x $1,5=10,5 \mathrm{~m}^{2}$ \\
\hline 6. Kaszálás (T4K+fükasza) & 1997.09.15. & Parcellánként 7 x 1,5 = 10,5 m² \\
\hline 1.Mütrágyázás (NPK) & 1998.03.12. & Parcellánként kézzel \\
\hline 2.Bonitálás zöldbimbós korban & 1998.05.15. & Parcellánként 1-5 skálán \\
\hline 3.Kaszálás (T4K+fükasza) & 1998.05.15. & Parcellánként 7 x 1,5 = 10,5 m² \\
\hline 4. Kaszálás (T4K+fükasza) & 1998.06.22. & Parcellánként 7 x 1,5 = 10,5 m² \\
\hline 5. Kaszálás (T4K+fükasza) & 1998.07.22. & Parcellánként 7 x $1,5=10,5 \mathrm{~m}^{2}$ \\
\hline 6. Kaszálás (T4K+fükasza) & 1998.09.02. & Parcellánként 7 x 1,5 = 10,5 m² \\
\hline 1.Műtrágyázás (NPK) & 1999.03.26. & Parcellánként kézzel \\
\hline 2.Kaszálás (T4K+fükasza) & 1999.05.17. & Parcellánként 7 x 1,5 = 10,5 m² \\
\hline 3.Kaszálás (T4K+fükasza) & 1999.06.29. & Parcellánként 7 x 1,5 = 10,5 m² \\
\hline 4. Kaszálás (T4K+fükasza) & 1999.07.29. & Parcellánként 7 x 1,5 = 10,5 m² \\
\hline 5.Tartlóhántás & 1999.08.17. & MTZ-80+tárcsa \\
\hline 6. Repce vetése & 1999.09.14. & \\
\hline
\end{tabular}

Megjegyzés: Vetés 1-2 cm mélyre, gabona sortávra $1200 \mathrm{db} / \mathrm{m}^{2}$ csíraszámmal és $24 \mathrm{~kg} . h a^{-1}$ vetőmagnormával

\section{Kísérleti eredmények}

Ezen a humuszos vályog csernozjom termöhelyen a N, Cu és Mo kezelések hatása a lucerna hozamaiban nem volt igazolható, ezért a szénaterméseket kaszálásonként és évenként közöljük 1996-1999 között a 4. táblázatban. Az első évben 1996. július végén egy gyomirtó kaszálásra került sor, a termést nem értékeltük. A szeptember végén végzett 2 . kaszáláskori sarjú $1,5 \mathrm{t} \cdot \mathrm{ha}^{-1}$ légszáraz tömeget adott. 
4. táblázat

Átlagos szénatermés kaszálásonként és évenként 1996-1999 között, t·ha ${ }^{-1}$ (Mészlepedékes csernozjom vályogtalaj, Mezőföld, Nagyhörcsök)

\begin{tabular}{|c|c|c|c|c|c|}
\hline $\begin{array}{c}\text { Évek } \\
(1)\end{array}$ & $\begin{array}{c}\text { 1.kaszálás } \\
(2)\end{array}$ & $\begin{array}{c}\text { 2.kaszálás } \\
(3)\end{array}$ & $\begin{array}{c}\text { 3.kaszálás } \\
(4)\end{array}$ & $\begin{array}{c}\text { 4.kaszálás } \\
(5)\end{array}$ & $\begin{array}{c}\text { Együtt } \\
(6)\end{array}$ \\
\hline \multicolumn{7}{|c}{} & & & \\
1996 & gyomirtó (7) & 1,4 & - & - & 1,4 \\
1997 & 4,4 & 4,0 & 2,0 & 0,6 & 11,0 \\
1998 & 4,0 & 2,8 & 1,8 & 0,8 & 9,4 \\
1999 & 4,8 & 3,0 & 2,6 & - & 10,4 \\
Együtt & & 11,2 & 6,4 & 1,4 & 32,2 \\
$(6)$ & 13,2 & & & & \\
\hline
\end{tabular}

Megjegyzés: A N, Cu, Mo kezelések a termés tömegét nem befolyásolták. A zöldbimbós állapotban betakarított lucerna átlagosan 20-25\% légszárazanyaggal rendelkezet

Az adatokat elemezve megállapítható, hogy a maximális hozamok az 1. kaszálásokhoz köthetők, majd az elöregedő lucerna termése csökken. Valójában a szeptemberi 4. kaszálás gazdaságossága 1997-ben és 1998-ban megkérdőjelezhető. Maximális teljesítményt a lucerna a 2 . évében nyújtotta $11 \mathrm{t} \cdot \mathrm{ha}^{-1}$ légszáraz széna tömeggel. A 4 év alatt összesen $32,2 \mathrm{t} \cdot \mathrm{ha}^{-1}$ széna képződött. Az adatokból az is látható, hogy az éves csapadékösszeg és a terméstömeg között nem volt összefüggés, hiszen a 2 . éves maximális teljesítmény a csapadékban legszegényebb évhez kötödik.

\section{5. táblázat}

N-szintek hatása a lucernaszéna elemtartalmára 1997-ben kaszálásonként (Mészlepedékes csernozjom vályogtalaj, Nagyhörcsök, Mezőföld)

\begin{tabular}{|c|c|c|c|c|c|c|c|c|}
\hline \multirow{2}{*}{$\begin{array}{l}\text { (1) N-szint } \\
\mathbf{k g} \cdot \mathbf{h a}^{-1} \mathbf{e ́}^{-1}\end{array}$} & \multicolumn{4}{|c|}{$\mathbf{N} \%$} & \multicolumn{4}{|c|}{$\mathrm{NO}_{3}-\mathrm{N}, \mathrm{mg} \cdot \mathrm{kg}^{-1}$} \\
\hline & 05.20 . & 06.30. & 08.05 . & 09.15 . & 05.20 . & 06.30. & 08.05 . & 09.15. \\
\hline 0 & 3,29 & 2,82 & 3,01 & 3,19 & 0,56 & 0,87 & 0,46 & 0,14 \\
\hline 100 & 3,63 & 2,82 & 3,17 & 3,24 & 1,71 & 0,87 & 0,51 & 0,15 \\
\hline 200 & 3,97 & 3,02 & 3,26 & 3,21 & 2,42 & 1,65 & 0,85 & 0,19 \\
\hline 300 & 3,81 & 3,14 & 3,27 & 3,27 & 2,64 & 1,89 & 1,20 & 0,25 \\
\hline (2) $\mathrm{SzD}_{5 \%}$ & 0,21 & 0,24 & 0,17 & 0,17 & 0,53 & 0,23 & 0,18 & 0,02 \\
\hline (3) Átlag & 3,67 & 2,95 & 3,18 & 3,23 & 1,83 & 1,32 & 0,76 & 0,18 \\
\hline \multirow{2}{*}{ 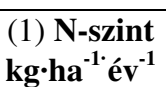 } & \multicolumn{3}{|c|}{ K \% } & Са \% & \multicolumn{3}{|c|}{ Mg \% } & Na mg.kg ${ }^{-1}$ \\
\hline & 05.20 . & 06.30. & 08.05 . & 08.05 . & 06.30. & 08.05 . & 09.15. & 05.20 \\
\hline 0 & 3,26 & 2,46 & 2,41 & 1,94 & 0,28 & 0,30 & 0,61 & 188 \\
\hline 100 & 3,09 & 2,32 & 2,27 & 2,02 & 0,29 & 0,34 & 0,76 & 286 \\
\hline 200 & 3,17 & 2,36 & 2,22 & 2,21 & 0,31 & 0,36 & 0,72 & 452 \\
\hline 300 & 2,96 & 2,29 & 2,11 & 2,26 & 0,31 & 0,34 & 0,73 & 548 \\
\hline (2) $\mathrm{SzD}_{5 \%}$ & 0,16 & 0,11 & 0,16 & 0,18 & 0,03 & 0,03 & 0,05 & 144 \\
\hline (3) Átlag & 3,12 & 2,36 & 2,25 & 2,11 & 0,30 & 0,34 & 0,70 & 368 \\
\hline
\end{tabular}


A N-kínálattal általában igazolhatóan emelkedett 1997-ben a széna összes Nkészlete, ezen belül kifejezetten a $\mathrm{NO}_{3}-\mathrm{N}$ mennyisége. A nitrát forma tartaléktápanyagnak minősül, hűen tükrözi a túlkínálatot 2-4-szeres akkumulációt mutatva. A K \%-a visszaesett, míg az antagonista $\mathrm{Ca}, \mathrm{Mg}$, $\mathrm{Na}$ elemek beépülése megnőtt. Különösen a mobilis $\mathrm{Na}$ kationé. A $\mathrm{N}$ és a $\mathrm{NO}_{3}-\mathrm{N}$ változása mind a négy kaszálás idején kimutatható, míg a $\mathrm{K}$ és a Mg változása három-három, a Ca és $\mathrm{Na}$ koncentrációjának módosulása csupán 1-1 kaszálás idején. A Ca az elöregedő szövetekben mérsékelten növekszik augusztusban, míg a $\mathrm{Na}$ a fiatal hajtásban többszöröződik a N-kínálattal az 5. táblázat adatai szerint.

6. táblázat

N-szintek hatása a lucerna széna elemtartalmára 1998-ban és 1999-ben kaszálásonként (Mészlepedékes csernozjom vályogtalaj, Nagyhörcsök, Mezöföld)

\begin{tabular}{|c|c|c|c|c|c|c|c|c|}
\hline \multirow{2}{*}{ 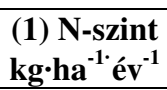 } & \multicolumn{2}{|c|}{$\mathbf{N} \%$} & \multirow{2}{*}{$\begin{array}{c}\mathbf{K} \% \\
06.22 .\end{array}$} & \multirow{2}{*}{$\begin{array}{l}\text { Са \% } \\
06.22 . \\
\end{array}$} & \multirow{2}{*}{$\frac{\text { Mg \% }}{06.22 .}$} & \multicolumn{3}{|c|}{$\mathrm{NO}_{3}-\mathrm{N} \mathrm{mg} \cdot \mathrm{kg}^{-1}$} \\
\hline & 05.15 . & 06.22 . & & & & 05.15 . & 06.22 . & 07.22 . \\
\hline \multicolumn{9}{|c|}{ 1998-ban (2) } \\
\hline 0 & 3,78 & 3,57 & 2,23 & 2,27 & 0,34 & 0,76 & 0,68 & 0,59 \\
\hline 100 & 3,91 & 3,57 & 2,04 & 2,28 & 0,38 & 1,22 & 0,73 & 0,58 \\
\hline 200 & 4,12 & 3,80 & 2,11 & 2,36 & 0,38 & 2,14 & 1,25 & 0,87 \\
\hline 300 & 4,62 & 3,79 & 2,00 & 2,51 & 0,37 & 2,64 & 1,58 & 1,28 \\
\hline (3) $\mathrm{SzD}_{5 \%}$ & 0,28 & 0,14 & 0,18 & 0,10 & 0,02 & 0,15 & 0,30 & 0,13 \\
\hline (4) Átlag & 4,11 & 3,68 & 2,09 & 2,35 & 0,37 & 1,69 & 1,06 & 0,83 \\
\hline \multirow{2}{*}{ 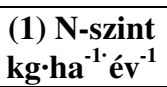 } & \multicolumn{3}{|c|}{ N\% } & \multicolumn{3}{|c|}{$\mathrm{K} \%$} & \multicolumn{2}{|c|}{$\mathrm{NO}_{3}-\mathrm{N} \mathrm{kg} \cdot \mathrm{ha}^{-1}$} \\
\hline & 05.17 . & 06.29 . & 07.29 . & 05.17 . & 06.29. & 07.29 . & 05.17. & 07.29 . \\
\hline \multicolumn{9}{|c|}{ 1999-ben (5) } \\
\hline 0 & 3,47 & 3,15 & 3,49 & 2,40 & 2,27 & 2,69 & 0,65 & 0,81 \\
\hline 100 & 3,72 & 3,37 & 3,64 & 2,25 & 2,22 & 2,64 & 0,94 & 0,79 \\
\hline 200 & 4,05 & 3,30 & 3,90 & 2,22 & 2,13 & 2,56 & 1,33 & 0,93 \\
\hline 300 & 4,15 & 3,62 & 3,82 & 2,21 & 2,03 & 2,42 & 1,58 & 1,00 \\
\hline (3) $\mathrm{SzD}_{5 \%}$ & 0,27 & 0,20 & 0,19 & 0,09 & 0,13 & 0,14 & 0,32 & 0,14 \\
\hline (4) Átlag & 3,85 & 3,36 & 3,71 & 2,27 & 2,16 & 2,58 & 1,13 & 0,88 \\
\hline
\end{tabular}

Hasonlóképpen jelentkezik a N-trágyázás hatása 1998-ban: nőtt a $\mathrm{N}$ és a $\mathrm{NO}_{3}$ $\mathrm{N}$, illetve ezzel együtt a Ca és $\mathrm{Mg}$, illetve mérséklődött a $\mathrm{K}$ beépülése. $\mathrm{A} N$ és a $\mathrm{NO}_{3}-\mathrm{N}$ akkumulációja és a K-felvétel gátlása 1999-ben is több kaszálás idején megfigyelhető (6. táblázat). 
7. táblázat

Légszáraz lucerna széna átlagos makroelemtartalma kaszálásonként és évenként, \% (Mészlepedékes csernozjom vályogtalaj, Nagyhörcsök, Mezőföld)

\begin{tabular}{|c|c|c|c|c|}
\hline \multirow{2}{*}{$\begin{array}{l}\text { Vizsgált } \\
\text { elemek (1) }\end{array}$} & \multicolumn{4}{|c|}{ 1997-ben (2) } \\
\hline & 05.20-án & 06.30-án & 08.05-én & 09.15-én \\
\hline $\mathrm{Ca}$ & 1,83 & 1,84 & 2,11 & 2,77 \\
\hline K & 3,12 & 2,36 & 2,25 & 1,29 \\
\hline $\mathrm{P}$ & 0,33 & 0,30 & 0,28 & 0,22 \\
\hline S & 0,36 & 0,38 & 0,38 & 0,45 \\
\hline $\mathrm{Mg}$ & 0,22 & 0,30 & 0,34 & 0,70 \\
\hline \multirow{2}{*}{$\begin{array}{l}\text { Vizsgált } \\
\text { elemek (1) }\end{array}$} & \multicolumn{4}{|c|}{ 1998-ban (3) } \\
\hline & 05.15-én & 06.22-én & 07.22-én & 09.02-án \\
\hline $\mathrm{Ca}$ & 2,07 & 2,35 & 2,27 & 2,49 \\
\hline $\mathrm{K}$ & 2,69 & 2,09 & 2,53 & 1,65 \\
\hline $\mathrm{P}$ & 0,37 & 0,31 & 0,31 & 0,31 \\
\hline $\mathrm{Mg}$ & 0,29 & 0,37 & 0,34 & 0,61 \\
\hline \multirow{2}{*}{$\begin{array}{l}\text { Vizsgált } \\
\text { elemek (1) }\end{array}$} & \multicolumn{3}{|c|}{ 1999-ben (4) } & 1996-ban (5) \\
\hline & 05.17-én & 06.29-én & 07.29-én & 09.30-án \\
\hline $\mathrm{Ca}$ & 2,00 & 1,63 & 1,98 & 3,18 \\
\hline K & 2,27 & 2,16 & 2,58 & 2,41 \\
\hline $\mathrm{P}$ & 0,35 & 0,29 & 0,34 & 0,42 \\
\hline $\mathrm{Mg}$ & 0,23 & 0,25 & 0,30 & 0,49 \\
\hline
\end{tabular}

Tanulságos megvizsgálni hogyan változik a lucerna széna néhány makroelemének tartalma a kaszálások és évek, illetve az elöregedés függvényében. A 7. táblázat eredményei szerint a $\mathrm{Ca}$ és $\mathrm{Mg}$ koncentrációja nő a korral és a kaszálások idejével. A Ca és $\mathrm{Mg}$ az „elöregedés” eleme. A K ezzel szemben közismerten fiatalít, élettanilag aktív, nedvdús fiatal szövetekben halmozódik fel. A P-tartalom változása nem egyértelmü, hol csökkent, hol nőtt az elöregedő növényben. A S esetében nem volt elég adatunk ahhoz, hogy megbízható következtetéseket vonjunk le.

A kísérlet indulásakor, 1988 tavaszán $\mathrm{CuSO}_{4}$ formában beszántott sóból a lucerna a 9-12. év után is képes volt a rezet felvenni és a hajtás, illetve a széna Cutartalmát 2-4 mg $\mathrm{kg}^{-1}$ értékkel, átlagosan 30-50\%-kal növelni. Megemlítjük, hogy a $\mathrm{Cu}$ felvételét 1997-ben, az 1. és a 2. kaszálások idején igazolhatóan serkentette a Ntrágyázás is átlagosan $1 \mathrm{mg} \cdot \mathrm{kg}^{-1}$ értékkel.

A Mo hasonló karbonátos talajban megtartja mobilitását és molibdenát formában marad a talajban. A Mo-nel nem szennyezett talajon a lucerna széna 2-5 $\mathrm{mg} \cdot \mathrm{kg}^{-1}$ közötti koncentrációkat mutatott és az elöregedéssel a Mo-tartalom mérséklődött a szénában. Az 1992-ben adott $48 \mathrm{~kg} \cdot \mathrm{ha}^{-1}$ Mo-trágyázás nyomán a széna Mo készlete általában egy nagyságrenddel megemelkedett. A koncentráció csökkenése a korral itt is megfigyelhetö (8. táblázat). 


\section{8. táblázat}

Mo-szintek hatása a légszáraz lucerna széna Mo-tartalmára kaszálásonként és évenként, $\mathrm{mg} \cdot \mathrm{kg}^{-1}$ (Mészlepedékes csernozjom vályogtalaj, Nagyhörcsök, Mezöföld)

\begin{tabular}{|c|c|c|c|c|}
\hline \multirow{2}{*}{$\begin{array}{l}\text { Vizsgált } \\
\text { évek (1) }\end{array}$} & \multicolumn{4}{|c|}{ Kaszálások száma (2) } \\
\hline & Első (3) & Második (4) & Harmadik (5) & Negyedik (6) \\
\hline \multicolumn{5}{|c|}{ Mo $=0 \mathrm{~kg} \cdot \mathrm{ha}^{-1}$} \\
\hline 1997 & 3,2 & 3,7 & 1,8 & 1,9 \\
\hline 1998 & 4,8 & 1,8 & 2,0 & 3,2 \\
\hline 1999 & 2,9 & 3,0 & 3,6 & - \\
\hline Átlag & 3,6 & 2,8 & 2,5 & 2,5 \\
\hline \multicolumn{5}{|c|}{ Mo $=48 \mathrm{~kg} \cdot \mathrm{ha}^{-1}$ 1992-ben (8) } \\
\hline 1997 & 69 & 39 & 30 & 22 \\
\hline 1998 & 29 & 26 & 26 & 24 \\
\hline 1999 & 36 & 18 & 24 & - \\
\hline Átlag (7) & 45 & 28 & 27 & 23 \\
\hline
\end{tabular}

\section{9. táblázat}

Mo-szintek hatása a lucerna széna egyéb elemtartalmára 1997-ben és 1998-ban (Mészlepedékes csernozjom vályogtalaj, Nagyhörcsök, Mezőföld)

\begin{tabular}{|c|c|c|c|c|c|c|}
\hline \multirow{2}{*}{$\begin{array}{l}\text { (1) Mo-szint } \\
\text { kg.ha- }{ }^{-} \cdot \mathbf{1 9 9 2}^{-1}\end{array}$} & $\mathbf{K}^{3}$ & $\mathrm{Ca}^{3}$ & $\mathbf{M g}_{1}$ & $\mathrm{NO}_{3}-\mathrm{N}^{3}$ & $\mathrm{Cu}^{3}$ & $\mathrm{Cu}^{4}$ \\
\hline & \multicolumn{2}{|c|}{$\%$} & \multicolumn{2}{|c|}{$\mathrm{mg}^{\prime} \mathrm{g}^{-1}$} & \multicolumn{2}{|c|}{$\mathrm{mg} \cdot \mathrm{kg}^{-1}$} \\
\hline \multicolumn{7}{|c|}{ 1997-ben (2) } \\
\hline 0 & 2,32 & 1,99 & 2,15 & 0,86 & 7,91 & 6,39 \\
\hline 48 & 2,19 & 2,22 & 2,30 & 0,65 & 7,26 & 6,04 \\
\hline $\mathrm{SzD}_{5 \%}(3)$ & 0,09 & 0,15 & 0,11 & 0,07 & 0,50 & 0,20 \\
\hline Átlag (4) & 2,25 & 2,11 & 2,23 & 0,76 & 7,58 & 6,21 \\
\hline \multirow{2}{*}{$\begin{array}{l}\text { (1) Mo-szint } \\
\text { kg.ha- }{ }^{-} \cdot \mathbf{1 9 9 2}^{-1}\end{array}$} & $\mathbf{N}^{1}$ & $\mathbf{N}^{3}$ & $\mathrm{Ca}^{3}$ & $\mathbf{N}^{1}$ & $\mathbf{N}^{3}$ & $\mathrm{NO}_{3}-\mathrm{N}^{3}$ \\
\hline & \multicolumn{3}{|c|}{$\%$} & & $\%$ & $\mathrm{mg} \cdot \mathrm{g}^{-1}$ \\
\hline \multicolumn{7}{|c|}{ 1998-ban (5) } \\
\hline 0 & 3,94 & 3,50 & 2,21 & 3,67 & 3,51 & 0,95 \\
\hline 48 & 4,27 & 3,61 & 2,33 & 4,02 & 3,91 & 0,81 \\
\hline $\mathrm{SzD}_{5 \%}(3)$ & 0,22 & 0,11 & 0,08 & 0,18 & 0,16 & 0,06 \\
\hline Átlag (4) & 4,11 & 3,56 & 2,27 & 3,85 & 3,71 & 0,88 \\
\hline
\end{tabular}

Megjegyzés: Az elemek indexe az adott kaszálás idejére mutat. $\mathrm{Pl}: \mathrm{K}^{3}=\mathrm{K} \%$-a a 3 . kaszáláskor

A széna takarmányozásra alkalmatlanná vált a Mo-kezelés eredményeképpen. A nemzetközi szakirodalom a $10 \mathrm{mg} \cdot \mathrm{kg}^{-1}$ feletti Mo-tartalmat már az egészségügyi határértéket meghaladónak, károsnak minősíti a takarmányban, mely tartós fogyasztás esetén molibdenózist, hasmenéssel járó mérgezést okozhat az állatban. 
Egyidejüleg Cu hiányát indukálva, amennyiben a 10 körüli optimális $\mathrm{Cu} / \mathrm{Mo}$ arány drasztikusan módosul (CHANEY 1982, SAUERBECK 1985, KLOKE et al. 1988).

A Mo-kezelés egyéb elemek beépülését is módosította. Mérséklődött a $\mathrm{K}, \mathrm{Cu}$ és a $\mathrm{NO}_{3}-\mathrm{N}$, valamint nőtt a $\mathrm{Ca}$ és a $\mathrm{Mg}$ a szénában 1997-ben. Az összes $\mathrm{N}$ igazolhatóan dúsult 1998 és 1999-ben. Kimutatható volt még a Ca emelkedése és a $\mathrm{NO}_{3}$-N csökkenése 1997-hez hasonlóan. A N-Mo elemek közötti szinergizmus ismert. A N-kötő talajbani mikroorganizmusok specifikus katalizátora a Mo. A talaj N-kínálata tehát nőhet a Mo-trágyázással. A növények $\mathrm{NO}_{3}$-redukciójához szintén Mo szükséges. A Mo-trágyázással a $\mathrm{NO}_{3}-\mathrm{N}$ mérséklődhet, míg a fehérjeképződés javulhat, melyet az összes $\mathrm{N}$-tartalom emelkedése is jelezhet (9. táblázat).

10. táblázat

A lucerna széna minimum-maximum és átlagos elemtartalma, illetve összes és fajlagos elemfelvétele 1996-1999 között (Mészlepedékes csernozjom vályogtalaj, Nagyhörcsök, Mezőföld)

\begin{tabular}{|c|c|c|c|c|c|c|}
\hline $\begin{array}{l}\text { Elem } \\
\text { jele (1) }\end{array}$ & $\begin{array}{c}\text { Mérték- } \\
\text { egység } \\
(2)\end{array}$ & $\begin{array}{c}\text { Min/max. } \\
\text { tartalom } \\
(3)\end{array}$ & $\begin{array}{c}\text { Átlagos } \\
\text { tartalom } \\
(4)\end{array}$ & $\begin{array}{c}\text { Mérték- } \\
\text { egység } \\
(2)\end{array}$ & $\begin{array}{l}\text { Összes } \\
\text { felvétel } \\
(5)\end{array}$ & $\begin{array}{c}\text { Fajlagos } \\
1 \text { t szénára (6) }\end{array}$ \\
\hline $\mathrm{N}$ & $\%$ & $2,82-4,62$ & 3,72 & $\mathrm{~kg} \cdot \mathrm{ha}^{-1}$ & 1190 & 37 \\
\hline K & $\%$ & $1,65-3,26$ & 2,46 & $\mathrm{~kg} \cdot \mathrm{ha}^{-1}$ & 787 & 25 \\
\hline $\mathrm{Ca}$ & $\%$ & $1,63-3,18$ & 2,40 & $\mathrm{~kg} \cdot \mathrm{ha}^{-1}$ & 768 & 24 \\
\hline $\mathrm{Mg}$ & $\%$ & $0,22-0,73$ & 0,48 & $\mathrm{~kg} \cdot \mathrm{ha}^{-1}$ & 154 & 5 \\
\hline S & $\%$ & $0,36-0,45$ & 0,40 & $\mathrm{~kg} \cdot \mathrm{ha}^{-1}$ & 128 & 4 \\
\hline $\mathrm{P}$ & $\%$ & $0,22-0,42$ & 0,32 & $\mathrm{~kg} \cdot \mathrm{ha}^{-1}$ & 102 & 3 \\
\hline $\mathrm{Na}$ & $\mathrm{mg} \cdot \mathrm{kg}^{-1}$ & $188-548$ & 368 & $\mathrm{~g} \cdot \mathrm{ha}^{-1}$ & 11776 & 368 \\
\hline $\mathrm{Fe}$ & $\mathrm{mg} \cdot \mathrm{kg}^{-1}$ & $80-433$ & 256 & $\mathrm{~g} \cdot \mathrm{ha}^{-1}$ & 8192 & 256 \\
\hline $\mathrm{Al}$ & $\mathrm{mg} \cdot \mathrm{kg}^{-1}$ & $34-316$ & 175 & $\mathrm{~g} \cdot \mathrm{ha}^{-1}$ & 5600 & 175 \\
\hline $\mathrm{Sr}$ & $\mathrm{mg} \cdot \mathrm{kg}^{-1}$ & $92-152$ & 122 & $\mathrm{~g} \cdot \mathrm{ha}^{-1}$ & 3904 & 122 \\
\hline $\mathrm{Mn}$ & $\mathrm{mg} \cdot \mathrm{kg}^{-1}$ & $40-108$ & 74 & $\mathrm{~g} \cdot \mathrm{ha}^{-1}$ & 2368 & 74 \\
\hline B & $\mathrm{mg} \cdot \mathrm{kg}^{-1}$ & $42-89$ & 66 & $\mathrm{~g} \cdot \mathrm{ha}^{-1}$ & 2112 & 66 \\
\hline $\mathrm{Zn}$ & $\mathrm{mg} \cdot \mathrm{kg}^{-1}$ & $9-17$ & 13 & $\mathrm{~g} \cdot \mathrm{ha}^{-1}$ & 416 & 13 \\
\hline $\mathrm{Ba}$ & $\mathrm{mg} \cdot \mathrm{kg}^{-1}$ & $6-12$ & 9 & $\mathrm{~g} \cdot \mathrm{ha}^{-1}$ & 288 & 9 \\
\hline $\mathrm{Cu}$ & $\mathrm{mg} \cdot \mathrm{kg}^{-1}$ & $6-12$ & 8 & $\mathrm{~g} \cdot \mathrm{ha}^{-1}$ & 256 & 8 \\
\hline Mo & $\mathrm{mg} \cdot \mathrm{kg}^{-1}$ & $2-5$ & 3 & $\mathrm{~g} \cdot \mathrm{ha}^{-1}$ & 96 & 3 \\
\hline Mo* & $\mathrm{mg} \cdot \mathrm{kg}^{-1}$ & $18-69$ & 35 & $\mathrm{~g} \cdot \mathrm{ha}^{-1}$ & 1131 & 35 \\
\hline
\end{tabular}

Megjegyzés: 32 t·ha ${ }^{-1}$ összes szénahozammal és átlagos tartalommal számolva. A Ni 0,4-0,6 $\mathrm{mg} \cdot \mathrm{kg}^{-1}$ között változott, az As, $\mathrm{Cd}, \mathrm{Co}, \mathrm{Cr}, \mathrm{Hg}, \mathrm{Pb}, \mathrm{Se}$ általában $0,1-0,5 \mathrm{mg} \cdot \mathrm{kg}^{-1}$ kimutatási határ alatt maradt. Mo* szennyezett talajon

A lucerna széna extrém és becsült átlagos elemtartalmáról és a 4 év alatt a 32 t ha ${ }^{-1}$ összes szénahozamba épült elemek mennyiségéröl a 10. táblázat informál. Látható, hogy a minimum és a maximum koncentrációk széles határok között 
ingadozhatnak a kezelések, kaszálások és az évek függvényében. A hiperakkumulációt jelző Mo esetében a Mo-kezelések bemutatásától eltekintettünk. A 12 kaszálással becsléseink szerint $1190 \mathrm{~kg} \mathrm{~N}, 787 \mathrm{~kg} \mathrm{~K}(944$ kg K $2 \mathrm{O}), 768 \mathrm{~kg} \mathrm{Ca}$ (1075 kg CaO), $154 \mathrm{~kg} \mathrm{Mg} \mathrm{(257} \mathrm{kg} \mathrm{MgO),} 128 \mathrm{~kg} \mathrm{~S}, 102 \mathrm{~kg} \mathrm{P}\left(234 \mathrm{~kg} \mathrm{P}_{2} \mathrm{O}_{5}\right)$, kereken $12 \mathrm{~kg} \mathrm{Na}, 8 \mathrm{~kg} \mathrm{Fe}, 5-6 \mathrm{~kg} \mathrm{Al}, 4 \mathrm{~kg} \mathrm{Sr}, 2 \mathrm{~kg} \mathrm{Mn}$ és B távozhatott hektáronként.

$\mathrm{Az} 1 \mathrm{t}$ széna képződéséhez szükséges úgynevezett fajlagos elemigény kísérletünkben az alábbinak adódott: $37 \mathrm{~kg} \mathrm{~N}, 25 \mathrm{~kg} \mathrm{~K}(28 \mathrm{~kg} \mathrm{~K} 2 \mathrm{O}), 24 \mathrm{~kg} \mathrm{Ca}(34$ $\mathrm{kg} \mathrm{CaO}), 5 \mathrm{~kg} \mathrm{Mg}(8 \mathrm{~kg} \mathrm{MgO}), 3 \mathrm{~kg} \mathrm{P}\left(7 \mathrm{~kg} \mathrm{P}_{2} \mathrm{O}_{5}\right)$. Adataink felhasználhatók a lucerna elemigényének számításakor a szaktanácsadásban. Hasonló talajon a $\mathrm{N}$ pótlásától eltekinthetünk, hiszen kísérletünkben $\mathrm{N}$-hatásokat nem kaptunk. Lucerna N-igényét a légköri N-kötés fedezheti. A hazai szaktanácsadás számára ANTAL (2005) az alábbi fajlagosokat közli: $27 \mathrm{~kg} \mathrm{~N}, 15 \mathrm{Kg} \mathrm{K}_{2} \mathrm{O}, 35 \mathrm{~kg} \mathrm{CaO}, 7 \mathrm{~kg} \mathrm{P}_{2} \mathrm{O}_{5}, 3$ $\mathrm{kg} \mathrm{MgO}$. Összevetve megállapítható, hogy a szaktanácsadásnak ajánlott fajlagosok közül a N, K, Mg jelentősen eltér, kisebb értéket képvisel az ajánlás. Kísérleti körülményeink között a N-bőséggel túlzott elemakkumuláció járt együtt.

\section{Összefoglalás}

Mészlepedékes csernozjom vályogtalajon beállított szabadföldi kísérletben vizsgáltuk a NxCuxMo elemek közötti kölcsönhatásokat 1996-1999-ben lucernával. Termőhely talaja a szántott rétegben 3\% humuszt, 5\% körüli $\mathrm{CaCO}_{3}$-ot és $20 \%$ körüli agyagot tartalmazott. Talajelemzések alapján a terület jó $\mathrm{Ca}, \mathrm{Mg}, \mathrm{K}, \mathrm{Mn}$, kielégítő $\mathrm{Cu}$, valamint gyenge-közepes $\mathrm{P}$ és Zn ellátottságú volt. A talajvíz 13-15 m mélyen található, a terület aszályérzékeny. A kísérletet $4 \mathrm{~N}$ x $3 \mathrm{Cu}=12$ kezelés x 3 ismétlés $=36$ parcellával állítottuk be osztott parcellás (split-plot) elrendezéssel. A $\mathrm{N} 0,100,200,300 \mathrm{~kg} \cdot \mathrm{ha}^{-1}$, a $\mathrm{Cu} 0,50,100 \mathrm{~kg} \cdot \mathrm{ha}^{-1}$ adagokat jelentett Caammóniumnitrát, illetve $\mathrm{CuSO}_{4}$ formájában. A kísérlet 5. évében a $15 \mathrm{~m}$ hosszú parcellákat megfeleztük és $1 \mathrm{~m}$-es úttal elválasztottuk. A kísérlet sávos split-plot elrendezésüvé vált $4 \mathrm{Nx} 3 \mathrm{Cux} 2 \mathrm{Mo}=24$ kezelés $\mathrm{x} 3$ ismétlés $=72$ parcellával. A 48 $\mathrm{kg} \cdot h \mathrm{~h}^{-1} \mathrm{Mo}-\mathrm{t}\left(\mathrm{NH}_{4}\right) 6 \mathrm{Mo}_{7} \mathrm{O}_{24} \cdot 4 \mathrm{H}_{2} \mathrm{O}$ formában alkalmaztuk. Föbb eredmények:

- Ezen a humuszos vályog csernozjom talajon az alkalmazott $\mathrm{N}, \mathrm{Cu}, \mathrm{Mo}$ kezelések hatása nem jelentkezett. A vizsgált 4 év (1996-1999) alatt összesen 32 t·ha ${ }^{-1}$ széna képződött. Maximális hozamok (4-5 thha $\left.{ }^{-1}\right)$ az 1 . kaszálásokhoz kötődtek. Éveket tekintve a 2. lucernaév teljesítménye volt a legnagyobb $11 \mathrm{t}^{\mathrm{h}} \mathrm{ha}^{-1}$ hozammal.

- A N-kínálattal nőtt a $\mathrm{N}, \mathrm{NO}_{3}-\mathrm{N}, \mathrm{Ca}, \mathrm{Mg}, \mathrm{Na}$ és esetenként a $\mathrm{Cu}$, valamint mérséklődött a $\mathrm{K}$ beépülése a szénába. $\mathrm{A} \mathrm{CuSO}_{4} 10-12$ éves utóhatása nyomán a széna eredeti Cu-tartalma 30-50\%-kal, 2-4 mg $\mathrm{kg}^{-1}$ koncentrációval javult.

- A $48 \mathrm{~kg} \cdot \mathrm{ha}^{-1}$ egyszeri Mo-adag 5-8 év után is egy nagyságrenddel emelte a széna Mo-készletét, $18-69 \mathrm{mg} \cdot \mathrm{kg}^{-1}$ tartományba. Korral, kaszálásokkal a Motartalom csökkent. Ennek ellenére a széna takarmányozásra alkalmatlanná vált. A Mo-trágyázás az egyéb elemek beépülését is módosította: igazolhatóan növelte a $\mathrm{N}$, $\mathrm{Ca}, \mathrm{Mg}$, illetve mérsékelte a $\mathrm{K}, \mathrm{NO}_{3}-\mathrm{N}$, Cu felvételét. 
- A N-kötő talajbani mikroorganizmusok specifikus katalizátoraként a Mo növelheti a talaj $\mathrm{N}$-kínálatát és így a növényi $\mathrm{N}$-tartalmat. A növények $\mathrm{NO}_{3}$ redukciójához is Mo szükséges, így a $\mathrm{NO}_{3}-\mathrm{N}$ csökken, beépülve a fehérjékbe a Mo hatásra. Kísérletünkben érvényesült a $\mathrm{N}-\mathrm{Mo}, \mathrm{N}-\mathrm{Cu}$ szinergizmus, illetve $\mathrm{Mo}-\mathrm{NO}_{3}$ antagonizmus.

- Az évek, kaszálások és a kezelések nyomán a minimum-maximum elemtartalmak széles sávban változtak a szénában. A 12 kaszálással hektárra számolva a 4 év alatt összesen $1190 \mathrm{~kg} \mathrm{~N}, 787 \mathrm{~kg} \mathrm{~K}, 768 \mathrm{~kg} \mathrm{Ca}, 154 \mathrm{~kg} \mathrm{Mg}, 128 \mathrm{~kg}$ $\mathrm{S}, 102 \mathrm{~kg} \mathrm{P}, 12 \mathrm{~kg} \mathrm{Na}, 8 \mathrm{~kg} \mathrm{Fe}, 5 \mathrm{~kg} \mathrm{Al}, 4 \mathrm{~kg} \mathrm{Sr}, 2 \mathrm{~kg} \mathrm{Mn}$ és B felvétel történt. A beépült Zn 416, Ba 288, Cu 256, Mo $96 \mathrm{~g} \cdot$ ha $^{-1}$ mennyiségnek adódott. A Mo-nal kezelt talajon a Mo felvétele $1131 \mathrm{~g} \cdot \mathrm{ha}^{-1}$-t tett ki.

- Az $1 \mathrm{t}$ széna képződéséhez szükséges úgynevezett fajlagos elemtartalom $37 \mathrm{~kg}$ $\mathrm{N}, 25 \mathrm{~kg} \mathrm{~K}, 24 \mathrm{~kg} \mathrm{Ca}, 5 \mathrm{~kg} \mathrm{Mg}, 3 \mathrm{~kg} \mathrm{P}\left(7 \mathrm{~kg} \mathrm{P}_{2} \mathrm{O}_{5}\right)$ mennyiséget tett ki. Kísérleti viszonyaink között a túlzott $\mathrm{N}$-böséggel emelkedettebb fajlagos tartalom járt együtt. Lucerna N-igényét e talajon a légköri N-kötés fedezheti.

Kulcsszavak: Nitrogén Réz és Molibdén kölcsönhatások, tartamkísérlet, lucerna, mészlepedékes csernozjom talaj

\section{Irodalom}

ANTAL J. 2005.Növénytermesztéstan 1-2. Mezőgazda Kiadó. Budapest

BARANYAI F. FEKETE A. \& KovÁCS I. 1987. A magyarországi talaj tápanyagvizsgálatok eredményei. Mezőgazdasági Kiadó. Budapest.

BergmanN, W. 1992. Nutritional Disorders of Plants. Gustav Fischer Verlag. JenaStuttgart- New York.

Bowen, H.J.M. 1979. Environmental chemistry of the elements. Academic Press. New York.

BuZÁs I., Fekete A. BuzÁs Iné, Csengeri Pné \& Kovács AnÉ: 1979. Mütrágyázási irányelvek és üzemi számítási módszer. MÉM NAK. Budapest.

CHANEY, R.L. 1982. 9. Fate of toxic substances in sludge applies to cropland. In: Proc. Int. Symp. "Land Application of Sewage Sludge". 259-324. Tokyo, Japan.

EGNÉR, H., RIEHM, H. - DOMINGO, W.R. 1960. Untersuchungen über die chemische Bodenanalyse als Grundlage für die Beurteilung des Nährstoffzustandes der Böden. II. K-Lantbr. Högsk. Ann. 26:199-215.

GYŐRI D. 1984. A talaj termékenysége. Mezőgazdasági Kiadó. Budapest.

ISO 11261. 1995. Soil Quality Determination of total nitrogen. Modified Kjeldahl method. I.V.

KÁDÁR I. 1995. A talaj-növény-állat-ember tápláléklánc szennyeződése kémiai elemekkel Magyarországon. KTM-MTA TAKI. Budapest. 
KÁDÁR I. 2013. A gyepek mütrágyázásáról. MTA TAKI. Akaprint. Budapest. 357 p.

KÁDÁR I. - CSATHÓ P. 2017. A föbb makro- és mikroelemek közötti kölcsönhatások kísérletes vizsgálata. MTA TAKI. Budapest. 292 p.

KÁDÁR I. - SHALABY, M.H. 1985. N és Cu trágyázás hatása a talaj és a növény tápelemtartalmára. Növénytermelés. 34(2): 119-126.

KJELDAHL, J. 1891. Neue Methode zur Bestimmung des Stickstoffs in organischen Körpern. Zeitschr. f. analyt. Chemie. 22:366-382.

KLOKE ET AL. 1988. Das Drei-Bereiche-System für die Beurteilung von Böden mit Schadstoffbelastung. VDLUFA Schriftenreihe 28/2. Kongressband 11171127. VDLUFA-Verlag. Darmstadt.

LAKANEN, E. \& ERVIÖ, R. 1971. A comparison of eight extractants for the determination of plant available microelements in soils. Acta Agr. Fenn. 123:223-232.

MÉM NAK. (1978): A TVG tápanyagvizsgáló laboratórium módszerfüzete. MÉM Növényvédelmi és AGROKÉMIAI KÖZPONT. BUDAPEST.

SAUERBECK, D. 1985. Funktionen, Güte und Belastbarkeit des Bodens aus agriculturchemischer Sicht. Materialien zur Umweltforschung. Kohlhammer Verlag. Stuttgart.

SILLANPÄÄ M.: 1982. Micronutrients and the nutrient status of soils: a global study. FAO Soils Bulletin N. 48. Rome

TÖLGYESI GY. 1965. A keszthelyi lápon termett szálastakarmányok réz és molibdén tartalmának takarmányozási vonatkozásai. Magyar Állatorvosok Lapja. 20: 502-506.

TYURIN, I.V. 1937. Organicseszkoe vesesesztvo pocsvü. Szel'hozgiz. Moszkva.

VoIsIN, A. 1965. Fertilizer application. Soil, plant, animal. Crosby Lockwood. London.

\section{Interactions between nitrogen, copper and molybdenum in alfalfa (Medicago sativa L.)}

\section{KÁDÁR}

Institute for Soil Science and Agricultural Chemistry, Centre for Agricultural Research, Hungarian Academy of Sciences, Budapest

\section{Summary}

Interactions between the elements $\mathrm{N}, \mathrm{Cu}$ and Mo were studied on alfalfa in 1996-1999 in a field experiment set up on chernozem loam soil with lime deposits. The ploughed layer of the soil contained 3\% humus, around 5\% $\mathrm{CaCO} 3$ and around $20 \%$ clay. Soil analysis showed that the area was well supplied with $\mathrm{Ca}, \mathrm{Mg}, \mathrm{K}$ and $\mathrm{Mn}$ had satisfactory $\mathrm{Cu}$ content, but was only poorly or moderately supplied with $\mathrm{P}$ 
and $\mathrm{Zn}$. The groundwater depth was $13-15 \mathrm{~m}$ and the area was prone to drought. The experiment was originally set up in a split-plot design with $4 \mathrm{~N} \times 3 \mathrm{Cu}=12$ treatments in three replications, giving a total of 36 plots. The $\mathrm{N}$ rates, applied as calcium ammonium nitrate, were $0,100,200$ and $300 \mathrm{~kg} \cdot \mathrm{ha}-1$ and the $\mathrm{Cu}$ rates, in the form of $\mathrm{CuSO} 4$, were 0,50 and $100 \mathrm{~kg} \cdot \mathrm{ha}-1$. In the 5 th year of the experiment the $15 \mathrm{~m}$ long plots were halved and the two half-plots were separated by a $1 \mathrm{~m}$ path. The experiment thus became a strip-split-plot design, consisting of $4 \mathrm{~N} \times 3 \mathrm{Cu} \times 2 \mathrm{Mo}=24$ treatments in three replications, giving a total of 72 plots. The $48 \mathrm{~kg} \cdot \mathrm{ha}-1 \mathrm{Mo}$ was applied in the form of (NH4)6Mo7O24.4H2O. The main results were as follows:

- In this chernozem loam soil the $\mathrm{N}, \mathrm{Cu}, \mathrm{Mo}$ treatments did not affect the yield of alfalfa. During the four years studied (1996-1999), a total of 32 tha-1 of hay was harvested, with maximum yields (4-5 tha -1$)$ at the first mowing. Considering the years, the 2nd year of alfalfa was the most successful with a yield of $11 \mathrm{t} \cdot \mathrm{ha}-1$.

- With increasing rates of $\mathrm{N}$, the incorporation of $\mathrm{N}, \mathrm{NO}-\mathrm{N}, \mathrm{Ca}, \mathrm{Mg}, \mathrm{Na}$, and sometimes $\mathrm{Cu}$ increased, while that of $\mathrm{K}$ decreased in the hay. Due to the 10-12year residual effect of $\mathrm{CuSO} 4$ the original $\mathrm{Cu}$ content of the hay improved by 30 $50 \%$, i.e. $2-4 \mathrm{mg} \cdot \mathrm{kg}-1$.

- A single dose of $48 \mathrm{~kg} \cdot \mathrm{ha}-1$ Mo raised the hay Mo content by an order of magnitude to $18-69 \mathrm{mg} \cdot \mathrm{kg}-1$ even after $5-8$ years. The Mo content decreased with age and the number of mowings. Nevertheless, the hay became unsuitable for use as animal feed. Mo fertilization also influenced the incorporation of other elements, demonstrably increasing the uptake of $\mathrm{N}, \mathrm{Ca}$ and $\mathrm{Mg}$ and moderating that of $\mathrm{K}$, NO3-N and $\mathrm{Cu}$.

- As a specific catalyst for the N-binding microorganisms in the soil, Mo is able to increase the soil $\mathrm{N}$ supply and thus the $\mathrm{N}$ content of the plants. Mo is also necessary for NO3 reduction, so the quantity of NO3-N is reduced through incorporation into proteins in response to Mo. In the present experiment, N-Mo and $\mathrm{N}-\mathrm{Cu}$ synergism and Mo-NO3 antagonism were manifested.

- Due to the influence of the different years, mowings and treatments, the minimum and maximum element contents of the hay varied over a wide range. In 12 mowings over the course of four years a total of $1190 \mathrm{~kg} \mathrm{~N}, 787 \mathrm{~kg} \mathrm{~K}, 768 \mathrm{~kg}$ $\mathrm{Ca}, 154 \mathrm{~kg} \mathrm{Mg}, 128 \mathrm{~kg} \mathrm{~S}, 102 \mathrm{~kg} \mathrm{P}, 12 \mathrm{~kg} \mathrm{Na}, 8 \mathrm{~kg} \mathrm{Fe}, 5 \mathrm{~kg} \mathrm{Al}, 4 \mathrm{~kg} \mathrm{Sr}$ and $2 \mathrm{~kg}$ each of Mn and B was taken up per hectare, together with $416 \mathrm{~g} \mathrm{Zn}, 288 \mathrm{~g} \mathrm{Ba}, 256$ $\mathrm{g} \mathrm{Cu}$ and $96 \mathrm{~g}$ Mo per ha. The uptake of Mo was $1131 \mathrm{~g} \cdot \mathrm{ha}-1$ on Mo-treated soil.

- The specific nutrient content of $1 \mathrm{t}$ hay was $37 \mathrm{~kg} \mathrm{~N}, 25 \mathrm{~kg} \mathrm{~K}, 24 \mathrm{~kg} \mathrm{Ca}, 5 \mathrm{~kg}$ $\mathrm{Mg}$ and $3 \mathrm{~kg} \mathrm{P}$ (7 $\mathrm{kg}$ P2O5). $\mathrm{N}$ abundance was associated with elevated specific nutrient content under the given experimental conditions. On this soil atmospheric $\mathrm{N}$ fixation was able to cover the $\mathrm{N}$ requirements of alfalfa.

Key words: $\mathrm{N} \times \mathrm{Cu} \times \mathrm{Mo}$ interactions, long-term experiment, alfalfa, calcareous chernozem soil 


\section{Tables and figures}

Table 1. Crop sequence in the long-term $\mathrm{N} \times \mathrm{Cu}$ experiment between 1988 and 2003 (calcareous chernozem loam soil, Nagyhörcsök). (1) Year. (2) Crop species. (3) Cultivar/hybrid. (4) Spring barley. (5) Winter wheat. (6) Winter barley. (7) Maize. (8) Triticale. (9) Potato. (10) Oats. (11) Rye. (12) Alfalfa. (13) Rape. (14) Poppy. (15) Sunflower.

Table 2. Monthly and annual precipitation sums between 1995 and 1999, mm (calcareous chernozem loam soil, Nagyhörcsök). (1) Month. (2) Year. (3) 50year mean. (4) Annual total.

Table 3. Agronomic operations and observations in the long-term $\mathrm{N} \times \mathrm{Cu}$ experiment between 1996 and 1999 (calcareous chernozem loam soil, Nagyhörcsök). (1) Agronomic operations. (2) Date. (3) Other remarks.

Table 4. Mean hay yield per mowing and year between 1996 and 1999, t ha (calcareous chernozem loam soil, Nagyhörcsök). (1) Year. (2) $1^{\text {st }}$ mowing. (3) $2^{\text {nd }}$ mowing. (4) $3^{\text {rd }}$ mowing. (5) $4^{\text {th }}$ mowing. (6) Total. (7) Herbicide. Note: The $\mathrm{N}, \mathrm{Cu}$ and Mo treatments did not influence the yield quantity. Alfalfa harvested in the green bud stage had a mean air-dry matter content of $20-25 \%$.

Table 5. Effect of $\mathrm{N}$ levels on the element content of alfalfa hay in each mowing in 1997 (calcareous chernozem loam soil, Nagyhörcsök). (1) N level. (2) LSD $5 \%$. (3) Mean.

Table 6. Effect of $\mathrm{N}$ levels on the element content of alfalfa hay in each mowing in 1998 and 1999 (calcareous chernozem loam soil, Nagyhörcsök). (1) N level. (2) In 1998. (3) LSD $5 \%$. (4) Mean. (5) In 1999.

Table 7. Mean macroelement content of air-dry alfalfa per mowing and year, \% (calcareous chernozem loam soil, Nagyhörcsök). (1) Element. (2) In 1997. (3) In 1998. (4) In 1999. (5) In 1996.

Table 8. Effect of Mo levels on the Mo content of air-dry alfalfa per mowing and year, $\mathrm{mg} \mathrm{kg}^{-1}$ (calcareous chernozem loam soil, Nagyhörcsök). (1) Year. (2) Mowing. (3) First. (4) Second. (5) Third. (6) Fourth. (7) Mean. (8) In 1992.

Table 9. Effect of Mo levels on the contents of other elements in 1997 and 1998 (calcareous chernozem loam soil, Nagyhörcsök). (1) Mo level applied in 1992. (2) In 1997. (3) $\mathrm{LSD}_{5 \%}$. (4) Mean. (5) In 1998. Note: Numbers in superscript indicate the number of the mowing. e.g. $\mathrm{K}^{3}=\mathrm{K} \%$ in the third mowing.

Table 10. Minimum, maximum and mean element contents in alfalfa hay and the total and specific element uptake between 1996 and 1999 (calcareous chernozem loam soil, Nagyhörcsök). (1) Element. (2) Unit. (3) Min/max content. (4) Mean content. (5) Total uptake. (6) Specific uptake for $1 \mathrm{t}$ hay. Note: Calculated for $32 \mathrm{t} \mathrm{ha}^{-1}$ total hay yield and average content. The Ni content ranged from $0.4-0.6 \mathrm{mg} \mathrm{kg}^{-1}$, while that of $\mathrm{As}, \mathrm{Cd}, \mathrm{Co}, \mathrm{Cr}, \mathrm{Hg}, \mathrm{Pb}$ and Se was generally below the $0.1-0.5 \mathrm{mg} \mathrm{kg}^{-1}$ detection limit. Mo* on polluted soil. 